\title{
Evaluation and comparison of the antifertility potential activity and adverse effects of Trigonella foenum-graecum seeds and combined oral contraceptive pills in female rats
}

\author{
Ayah Rebhi Hilles ${ }^{1 *}$, Ahmad Kaid Allow ${ }^{1}$, Syed Mahmood ${ }^{2}$
}

\author{
${ }^{1}$ Department of Physiology, Kulliyyah of Medicine, International Islamic University Malaysia, Kuantan, Pahang, \\ Malaysia \\ ${ }^{2}$ Department of Pharmaceutical Technology, Kulliyyah of Pharmacy, International Islamic University Malaysia, \\ Kuantan, Pahang
}

Received: 28 December 2015

Revised: 23 January 2016

Accepted: 08 February 2016

\section{*Correspondence:}

Ayah Rebhi Hilles,

E-mail: ayah.hilles90@gmail.com

Copyright: ( ) the author(s), publisher and licensee Medip Academy. This is an open-access article distributed under the terms of the Creative Commons Attribution Non-Commercial License, which permits unrestricted non-commercial use, distribution, and reproduction in any medium, provided the original work is properly cited.

\section{ABSTRACT}

Background: Antifertility agents are one of the most common medication used in this modern era. In this research we used herbal plant Trigonella foenum-graecum (fenugreek) seeds to study the antifertility activity of Fenugreek Seeds allowed aqueous (FSA) extract in female rats compared with marketed combined oral contraceptive pills (COCPs) by evaluating Follicle Stimulating Hormone (FSH) level and to detect the adverse effects by determining the uterine weight, implantation rate, endometrial thickness, endometrial gland density and observing the histological uterine tissues.

Methods: Twenty four female Sprague Dawley strain rats of 8 weeks old were divided into four groups (A, B, C and D). Animals in Group A (positive control group) were not given any treatment and they were allowed to mate to become pregnant. Group B (negative control group) were not given any treatment as only female rats were kept. Group C (treated group) they were administered orally with $0.05 \mathrm{mg} / \mathrm{kg}$ body weight of COCPs for 15 days. Group D (treated group) they were administered orally with $750 \mathrm{mg} / \mathrm{kg}$ body weight of FSA extract for 15 days. The blood samples were taken after the both treatment on the proestrous phase to evaluate FSH level. In group A, C and D, 3 male rats of Spargue Dawley strain were also kept to do the mating process.

Results: Administration of $0.05 \mathrm{mg} / \mathrm{kg}$ of COCPs led to decrease the serum FSH concentration to $71.56 \mathrm{ng} / \mathrm{ml}$ while $750 \mathrm{mg} / \mathrm{kg}$ FSA extract led to decrease it to $25.62 \mathrm{ng} / \mathrm{ml}$, which shows that FSA extract is effective almost three times more than COCPs at higher dose. The uterine weight in the FSA extract treated group was normal, while the COCPs treated group was insignificantly high. The implantation rate was zero in all groups except the positive control group. The endometrial thickness in the FSA extract treated group was normal while in the COCPs increased. The endometrial gland density was normal in FSA extract treated group, while it decrease in COCPs treated group which a remarkable sign of endometrial atrophy. Histological endometrial tissues were normal in FSA extract treated group while COCPs treated group showed abnormal deciduiod cells (decidual like cells).

Conclusions: Administration of FSA extract decreased FSH concentration to almost three times more than OCCPs which show the high effectiveness of FSA extract more than marketed COCPs, not only that but it also showed no adverse effects in the uterine opposite with COCPs which guide us to alternative natural and safe contraceptive method.

Keywords: Antifertility, Fenugreek seeds, COCPs, FSH, Endometrial atrophy, Deciduiod cells 


\section{INTRODUCTION}

For decades, calls for more acceptable family planning options have been hindered by the inadequate attention and resources afforded to the contraceptive research and development field, as well as by a shift in the focus of remaining efforts from discovery to adaptation. ${ }^{1}$

Several factors make this a good time to reinvigorate the field of contraceptive research and development. These include an increasing understanding among international agencies and policymakers of the economic, social and personal costs of unintended pregnancy, and growing commitment to achieving universal access to family planning; ${ }^{2}$ the expansion of consumer markets in developing countries, which represent potentially profitable new markets for contraceptive products; ${ }^{3}$ a rising demand for contraceptives, because the number of reproductive age women is increasing in developing countries, and because the desire for smaller families, ${ }^{4}$ as well as advances in scientific knowledge and tools, which pave the way for the development of innovative contraceptive methods. ${ }^{1,5}$

There is a vital need to produce new contraceptive methods. What is needed is a broad array of contraceptive methods that require less complex distribution system, safer and less discomforting than current methods; that combine high acceptability with high continuity of use; and that are suited to the diverse requirements imposed by the variety of conditions throughout the world. ${ }^{6}$

Recently, oral contraceptive pills (OCPs) is the most common contraceptive method used worldwide. However, using OCPs has a lot of adverse effects such as venous thrombosis, myocardial infarction and worsening migraine. $^{8}$ Therefore, some women still rely on traditional herbs for family planning based on its common use for many years. These herbs are more affordable, easily available, and believed to cause fewer side effects. One of these herbs is Trigonella foenumgraecum (fenugreek) seeds, which is a famous an annual plant, cultivated worldwide as a semiarid crop. It has potential antifertility effect with minimal side effects and lower cost of production. ${ }^{9}$ The aim of ongoing research to focus on the potent antifertility activity of fenugreek seeds by comparing the effectiveness between Fenugreek seeds aqueous (FSA) extract with standard combined oral contraceptive pills (COCPs) to determine if fenugreek seeds can be as effective as COCPs.

\section{METHODS}

\section{Preparation of FSA extract}

Fenugreek seeds were purchased from a local shop from Yemen and cleared from the extraneous matter. Fenugreek seeds were prepared at the Herbal Research Laboratory of Kulliyyah of Pharmacy (KOP), (IIUM). The fenugreek seeds were blended into powder by using an electrical blender (LMS-1003, IKA WERKE, Malaysia). Then it was prepared by weighing $1 \mathrm{~g}$ of powder in $10 \mathrm{ml}$ distilled water. The solution was stirred on a magnetic stirrer for 24 hours and the dissolved fenugreek was taken, then the dissolved fenugreek was centrifuged for five minutes on $9000 \mathrm{rpm}$ by using centrifuge machine (Hanil, Supra 22k. south Korea), the supernatant was taken, then it was stored at $-80^{\circ} \mathrm{C}$ for 12 hours, then it was kept in freeze dryer machine (Martin Christ, Model Alpha 1-4, Germany) for seven days after that it can be kept at $-20^{\circ} \mathrm{C}$ until use as shown in Figure $1 .^{10}$

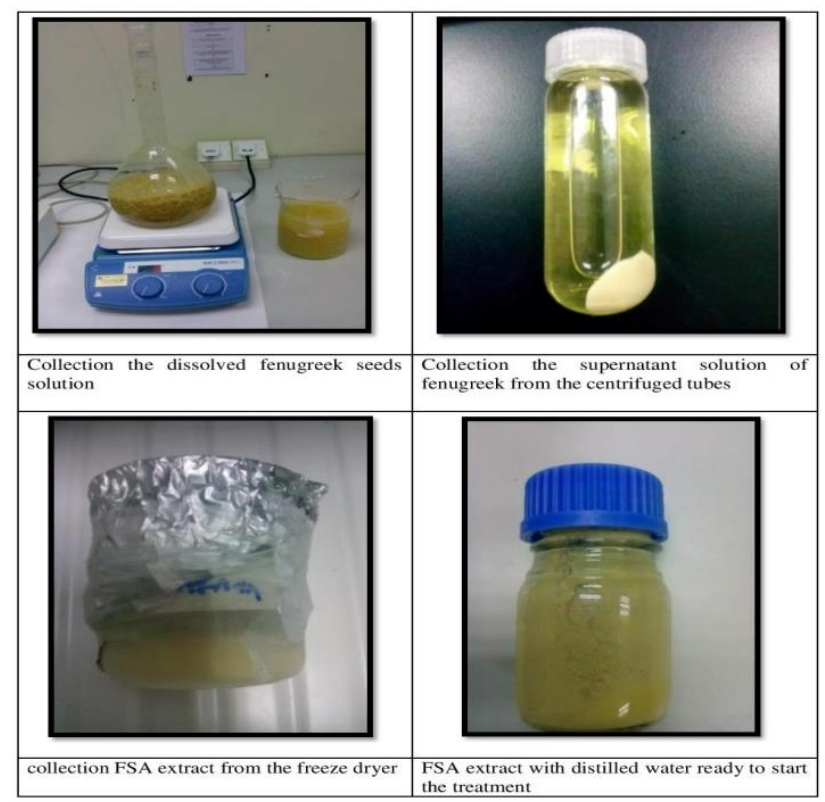

Figure 1: Preparation of FSA extract.

\section{COCPs}

COCPs tablets contain ethinyl estradiol and levonorgestrel were purchased from local pharmacy, the tablets were crushed into powder form. $10 \mathrm{mg}$ of the powder was dissolved in $1 \mathrm{ml}$ of propylene glycol at $37^{\circ} \mathrm{C} .^{11}$

\section{Animal study}

The animals used for this research were 24 females and 12 males adult healthy Sprague Dawley rats with average weight between 200 and 250 grams. Female rats were seven to eight weeks old. The rats were purchased from a licensed animal breeding house in Malaysia. They were housed with appropriate facilities and were kept under closely controlled environmental condition at $22^{\circ} \mathrm{C} \pm 2{ }^{\circ} \mathrm{C}$ room temprature with a $12 \mathrm{hr}$ light-dark cycle, humidity between $40-60 \%$. They were kept in metal cages and were treated in accordance with the Guidelines for the Care and Use of Laboratory Animals of the National Institutes of the Health. Procedures and handling of the animals were conducted in strict compliance to the approved institutional protocol and in accordance with 
the Guidelines for the Care and Use of Laboratory Animals of the Kulliyyah of Medicine, IIUM/IACUC/2015/(5) (27).

\section{Experimental design}

\section{Administration of FSA extract and COCPs into the animals}

After one week of acclimatization, the rats were randomly divided into four groups, each group has six female and three male rats; the first group positive control group, animals in group A didn't receive any treatment, they were mated to be pregnant. Animals in group B were negative control, they also didn't receive any treatment, as only female rats were kept. Animals in group $\mathrm{C}$ received $0.05 \mathrm{mg} / \mathrm{kg}$ of ethinyl estradiol from COCPs. Animals in Group D received $750 \mathrm{mg} / \mathrm{kg}$ of FSA extract. Prior to the administration of FSA extract and COCPs daily by using an orogastric tube for 15 days.

\section{Preparation of vaginal smears}

\section{Obtaining the sample}

Vaginal smear cytology of all 24 female rats was performed for 15 days during the treatment. The vaginal smears were detected every morning, from 9.00 am till $10.00 \mathrm{am}$, vaginal smears were collected by inserting a calibrated disposable plastic inoculation loop size $10 \mu \mathrm{L}$ (COPAN Diagnostics Inc, USA) into the vaginal opening. A swab was gently inserted at a relatively steep angle, after 1-2 inches of the swab was inserted, when the swab is fully inserted, the end of the inoculation loop was rotated through 2-3 revolutions, which will allow the tip of the loop to pick up an adequate load of cells and then gently withdrawn. The vaginal cells collected were transferred into a glass slide by rolling the loop tip along the length of the glass slide.

\section{Preparing and staining the smear}

The smear was prepared immediately after withdrawal the swab; the slides were dipped 5 to 10 times into $70 \%$ ethanol to fix it expeditiously. After fixation, the slides were stained by Methylene blue. A few drops were added to the slides for five minutes and then the slides were rinsed by running tap water, after that the slides were ready to be examined under the microscope.

\section{Microscopic examination}

The slides were examined using a standard laboratory light microscope (Olympus, Model CX 31, Japan). The four stages were distinguished by characteristic cell types that are visible during each stage, in addition differences in cell density. The descriptions and classification in this section relate specifically to the appearance of smears taken.
Three main cell types were seen in the vaginal smears: Cornified cells: large, angular and irregularly shaped, mostly non-nucleated when mature which is in the estrus phase. Epithelial cells: not quite as large as the cornified cells and much more rounded in shape, those seen at proestrous phase are mostly nucleated and with a granular appearance. Those seen at metestrous phase, it tend to be non-nucleated and less granular. Leucocytes: very small, round cells. Nuclei not usually evident at the low magnifications used. Epithelial and small cornified cells without the tightly packed clumps seen in diestrous phase.

\section{Blood collection procedure}

After 15 days of the treatment, blood was collected by retro orbital puncture technique. ${ }^{12}$ Vaginal smear cytology was performed on each rat prior to blood collection procedure to determine the estrous cycle. The blood was collected only when the animals were in the proestrous phase. The rats were anesthetized with an inhalation anesthetic ethyl ether. As soon as the rat was removed from the inhalation chamber, the anesthetized animal was rested on a flat surface, and held gently but firmly by the nape of the neck.

The eyeball was made to protrude by pressing the animal down with the thumb and forefinger just behind the eye and pulling back the skin. A sterile non-heparinized tube was pushed through the conjunctiva medially (inner side) of the ocular cavity while the tube was gently rotated until the plexus was reached, and filled with blood. The rat was hold facing down to allow the blood to drip into the collecting tubes.

After about $3 \mathrm{ml}$ of blood was collected, the nape of the neck was released slowly prior to withdrawal of the hematocrit tube to minimize hemorrhage from the puncture site. The animals were then placed into a separate recovery cage, observed them to ensure a safe recovery. Tubes of blood which collected from each animal were left to be clotted for 15 minutes, then it centrifuged (3000 rpm for 10 minutes), then the serum separated and kept in a $-20^{\circ} \mathrm{C}$ biomedical freezer (Sanyo, MDF-U5312, USA) until further biochemical assay procedure.

\section{Mating process}

After detection of proestrous "follicular phase" by vaginal smear, the rats were allowed to mate overnight. The next day vaginal smears were checked, when copulatory mucous plug holds the sperm that's detected, and this mucous plug holds the sperm and it is a sign of first day pregnancy which means the rats were successfully mated, if not the estrous cycle immediately repeated. 


\section{Histological analysis}

Fresh uterine tissues were fixed in $10 \%$ neutral formalin for histological studies. The tissues were processed by conventional technique, the sections of $5 \mu \mathrm{m}$ tissues were cut by (Manual Rotary Microtome, Leica RM2135) and paraffin-embedded center (EG 1160/Leica )was used to fix the tissues sections of $5 \mu \mathrm{m}$ thickness were prepared and stained with hematoxylin and eosin for microscopic (Leica IC50 HD) examination.

\section{Biochemical assay}

The biochemical assays of FSH was performed by using Enzyme Linked Immunosorbent Assay (ELISA) kit for rats hormone FSH (Follicle Stimulating Hormmone), catalog number E-EL-R0391 (Elabscience, Mutiara Saintifik).

\section{Statistical analysis}

The data from this study were analysed using Statistical Package for the Social Sciences IBM SPSS software, version 20.0. Comparison of the data was done using one way analysis of variance (ANOVA) followed by Dunnette's post hoc test. Data was expressed as mean \pm SEM. Statistically significant level was taken to be $\mathrm{p}$ value less than 0.05 .

\section{RESULTS}

\section{Comparison of serum FSH concentrations in the four groups}

After the proestrous phase has been detected as shown in Figure 2, the blood has been collected to measure the serum FSH concentration. The lowest concentration of FSH was in the FSA extract treated group, it has revealed that the values were statistically significant $\mathrm{P}<0.001$ followed by the COCPs treated group which also revealed that the values were statistically significant with $\mathrm{P}<0.001$, then the negative control group (not pregnant rats) and at the end, the highest concentration of FSH was in the positive control group (pregnant rats). The mean values were expressed as the Mean \pm SD as shown in Table 1. The differences in the standard error for the four groups shown in Figure 8.

\section{Comparison of the uterine weight in the four groups}

The highest uterine weight was in the positive control group (pregnant rats) followed by the COCPs treated group, it was slightly high which revealed that the values were statistically not significant with $\mathrm{P}<0.102$, while the negative control group (not pregnant rats) was as same as the FSA treated group with normal uterine weight range. The mean values were expressed as the Mean \pm SD as shown in Table 2, the differences in the standard error for the four groups shown in Figure 8.

\section{Comparison of the implantation rate in the four groups}

The implantation rate in the positive control group (pregnant rat) was found to be 10.6667 but in the other groups (negative; not pregnant group, COCPs treated group and FSA extract treated group) was found to be zero which revealed that the values were statistically significant with $\mathrm{P}<0.001$ in the positive control group compared with other groups. The implantation rat was done manually by counting the number of foetuses in the uterus as shown in Figure 3.

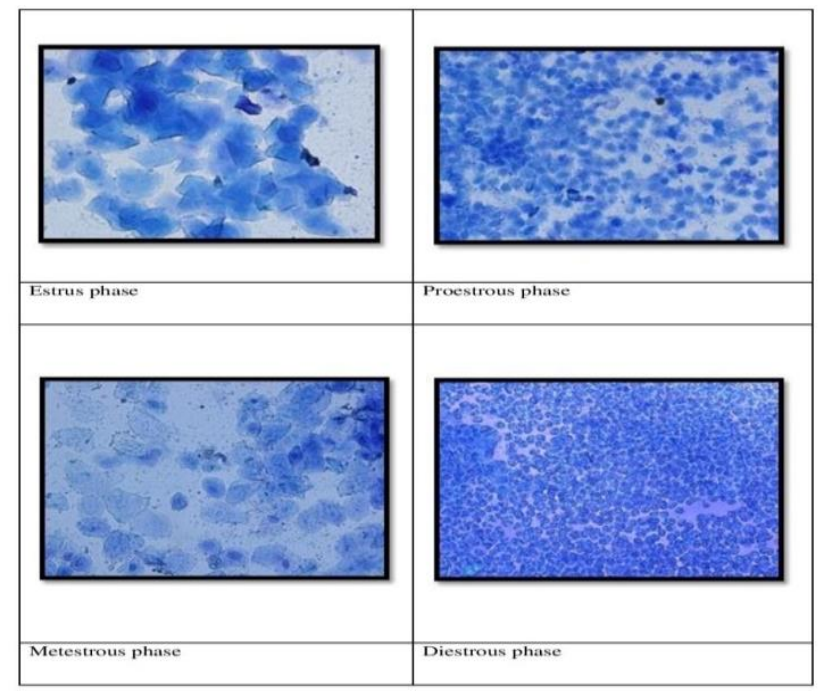

Figure 2: Stained vaginal smear by methylene blue shows the estrus cycle phase.

Table 1: The differences of serum FSH concentrations in the four groups, the mean values were expressed as the Mean \pm SD.

\begin{tabular}{|c|c|c|c|c|}
\hline $\begin{array}{l}\text { Female } \\
\text { rats }\end{array}$ & $\begin{array}{l}\text { negative } \\
\text { control } \\
\text { group (not } \\
\text { pregnant } \\
\text { rats) }\end{array}$ & $\begin{array}{l}\text { positive } \\
\text { control } \\
\text { group } \\
\text { (pregna } \\
\text { nt rats) }\end{array}$ & $\begin{array}{l}\text { COCPs } \\
\text { treated } \\
\text { group }\end{array}$ & $\begin{array}{l}\text { FSA } \\
\text { extract } \\
\text { treated } \\
\text { group }\end{array}$ \\
\hline $\begin{array}{l}\text { Female } \\
\text { rat } 1\end{array}$ & $\begin{array}{l}177.10 \\
\mathrm{ng} / \mathrm{ml}\end{array}$ & $\begin{array}{l}81.5 \\
\mathrm{ng} / \mathrm{ml}\end{array}$ & $\begin{array}{l}68.9 \\
\mathrm{ng} / \mathrm{ml}\end{array}$ & $\begin{array}{l}34 \\
\mathrm{ng} / \mathrm{ml}\end{array}$ \\
\hline $\begin{array}{l}\text { Female } \\
\text { rat } 2\end{array}$ & $\begin{array}{l}185.50 \\
\mathrm{ng} / \mathrm{ml}\end{array}$ & $\begin{array}{l}88.2 \\
\mathrm{ng} / \mathrm{ml}\end{array}$ & $\begin{array}{l}49.5 \\
\mathrm{ng} / \mathrm{ml}\end{array}$ & $\begin{array}{l}22.9 \\
\mathrm{ng} / \mathrm{ml}\end{array}$ \\
\hline $\begin{array}{l}\text { Female } \\
\text { rat } 3\end{array}$ & $\begin{array}{l}184.20 \\
\mathrm{ng} / \mathrm{ml}\end{array}$ & $\begin{array}{l}86.9 \\
\mathrm{ng} / \mathrm{ml}\end{array}$ & $54 \mathrm{ng} / \mathrm{ml}$ & $\begin{array}{l}30 \\
\mathrm{ng} / \mathrm{ml}\end{array}$ \\
\hline $\begin{array}{l}\text { Female } \\
\text { rat } 4\end{array}$ & $\begin{array}{l}183.50 \\
\mathrm{ng} / \mathrm{ml}\end{array}$ & $\begin{array}{l}79.5 \\
\mathrm{ng} / \mathrm{ml}\end{array}$ & $\begin{array}{l}70.4 \\
\mathrm{ng} / \mathrm{ml}\end{array}$ & $\begin{array}{l}18.4 \\
\mathrm{ng} / \mathrm{ml}\end{array}$ \\
\hline $\begin{array}{l}\text { Female } \\
\text { rat } 5\end{array}$ & $\begin{array}{l}183 \\
\mathrm{ng} / \mathrm{ml}\end{array}$ & $\begin{array}{l}88.2 \\
\mathrm{ng} / \mathrm{ml}\end{array}$ & $\begin{array}{l}81.3 \\
\mathrm{ng} / \mathrm{ml}\end{array}$ & $\begin{array}{l}23.2 \\
\mathrm{ng} / \mathrm{ml}\end{array}$ \\
\hline $\begin{array}{l}\text { Female } \\
\text { rat } 6\end{array}$ & $\begin{array}{l}200 \\
\mathrm{ng} / \mathrm{ml}\end{array}$ & $\begin{array}{l}95.5 \\
\mathrm{ng} / \mathrm{ml}\end{array}$ & $\begin{array}{l}115 \\
\mathrm{ng} / \mathrm{ml}\end{array}$ & $\begin{array}{l}28.6 \\
\mathrm{ng} / \mathrm{ml}\end{array}$ \\
\hline $\begin{array}{l}\text { Mean } \pm \\
\text { SD }\end{array}$ & $\begin{array}{l}185.71 \pm \\
1.51\end{array}$ & $\begin{array}{l}86.63 \pm \\
4.077\end{array}$ & $\begin{array}{l}73.518 \pm \\
11.59\end{array}$ & $\begin{array}{l}26.18 \pm \\
2.80\end{array}$ \\
\hline
\end{tabular}


Table 2: The differences of the uterine weight in the four groups, the mean values were expressed as the Mean \pm SD.

\begin{tabular}{|lllll|}
\hline Groups & $\begin{array}{l}\text { negative } \\
\text { control } \\
\text { group (not } \\
\text { pregnant } \\
\text { rats) }\end{array}$ & $\begin{array}{l}\text { positive } \\
\text { control } \\
\text { group } \\
\text { pregnant } \\
\text { rats) }\end{array}$ & $\begin{array}{l}\text { COCPs } \\
\text { treated } \\
\text { group }\end{array}$ & $\begin{array}{l}\text { FSA } \\
\text { extract } \\
\text { treated } \\
\text { group }\end{array}$ \\
\hline $\begin{array}{l}\text { Femats } \\
\text { rat 1 }\end{array}$ & 0.4421 & 4.2579 & 0.8689 & 0.4922 \\
\hline $\begin{array}{l}\text { Female } \\
\text { rat 2 }\end{array}$ & 0.4689 & 4.8683 & 0.8925 & 0.4224 \\
\hline $\begin{array}{l}\text { Female } \\
\text { rat 3 }\end{array}$ & 0.4378 & 3.2761 & 0.8321 & 0.4501 \\
\hline $\begin{array}{l}\text { Female } \\
\text { rat 4 }\end{array}$ & 0.4208 & 3.7169 & 0.8084 & 0.4615 \\
\hline $\begin{array}{l}\text { Female } \\
\text { rat 5 }\end{array}$ & 0.4764 & 4.9865 & 0.8654 & 0.4271 \\
\hline $\begin{array}{l}\text { Female } \\
\text { rat 6 }\end{array}$ & 0.4621 & 4.1649 & 0.8186 & 0.4837 \\
\hline $\begin{array}{l}\text { Mean } \pm \\
\text { SD }\end{array}$ & $\begin{array}{l}0.4513 \pm \\
0.26\end{array}$ & $\begin{array}{l}4.2117 \pm \\
0.25\end{array}$ & $\begin{array}{l}0.8476 \\
\pm 0.01\end{array}$ & $\begin{array}{l}0.4561 \\
\pm 0.24\end{array}$ \\
\hline
\end{tabular}

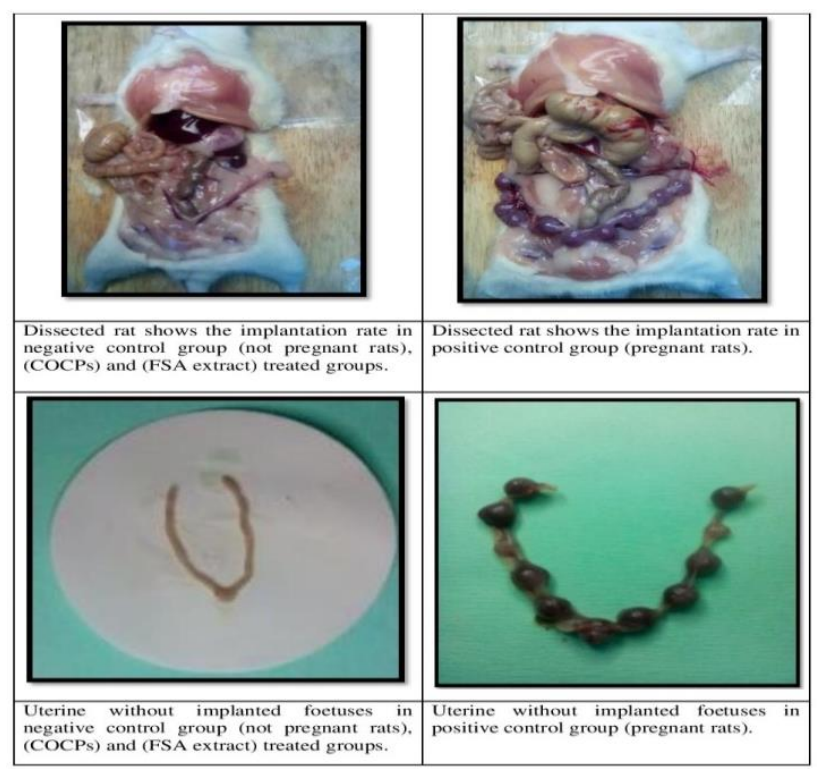

Figure 3: Implantation rate in negative control group (not pregnant rats), (COCPs), (FSA extract) treated groups and positive control group (pregnant rats).

\section{Comparison of the endometrial thickness in the four groups}

As shown in Figure 4, 5 the endometrial thickness observed with a magnification power $4 \mathrm{x}$ for all groups, in the negative control group (not pregnant rat) was recorded $(177.37 \pm 21.57) \mathrm{mm}$, followed by FSA extract treated group which was $(159.02 \pm 21.68) \mathrm{mm}$ while in COCPs 1 treated group which the rats were immediately sacrificed after stopping the treatment, the endometrial thickness was to be found $(41.60 \pm 20.17) \mathrm{mm}$, the values were statistically significant with $\mathrm{p}<0.001$. The endometrial thickness in the COCPs2 treated group which the rats were sacrificed after 15 days of stopping the treatment, the endometrial thickness was to be found recorded $(100.71 \pm 3.62) \mathrm{mm}$ as for our observation, the values were statistically significant with $p<0.001$. All the values were expressed as the Mean \pm SD. The lowest endometrial thickness was in the COCPs1 treated group, followed by the COCPs 2 treated group, then the negative control group (not pregnant rats) and FSA extract treated group which were both the highest endometrial thickness, the standard error shows these differences in Figure 8.

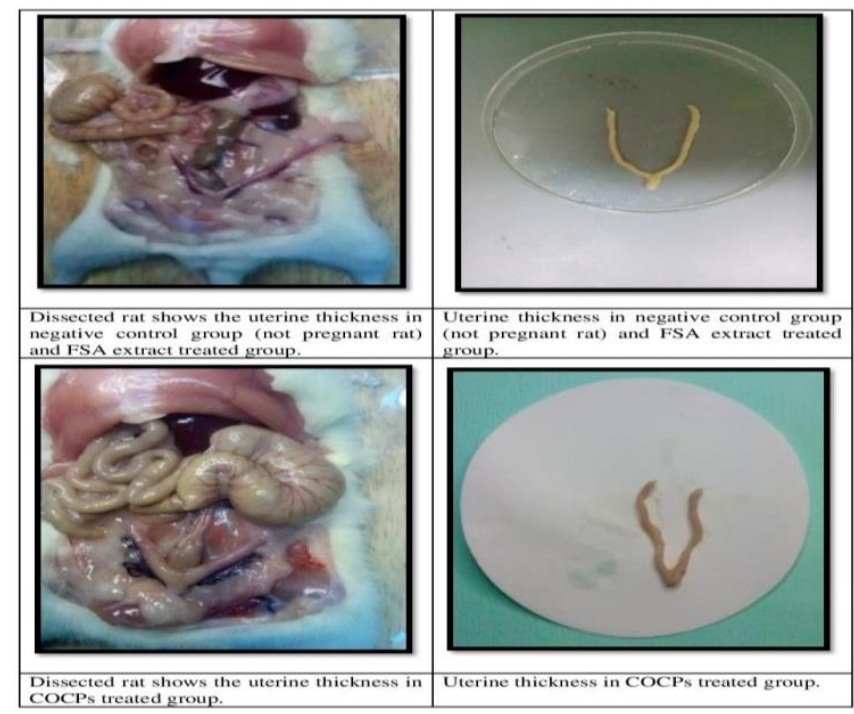

Figure 4: The uterine thickness in negative control group (not pregnant rats), (FSA extract) and COCPs treated group.

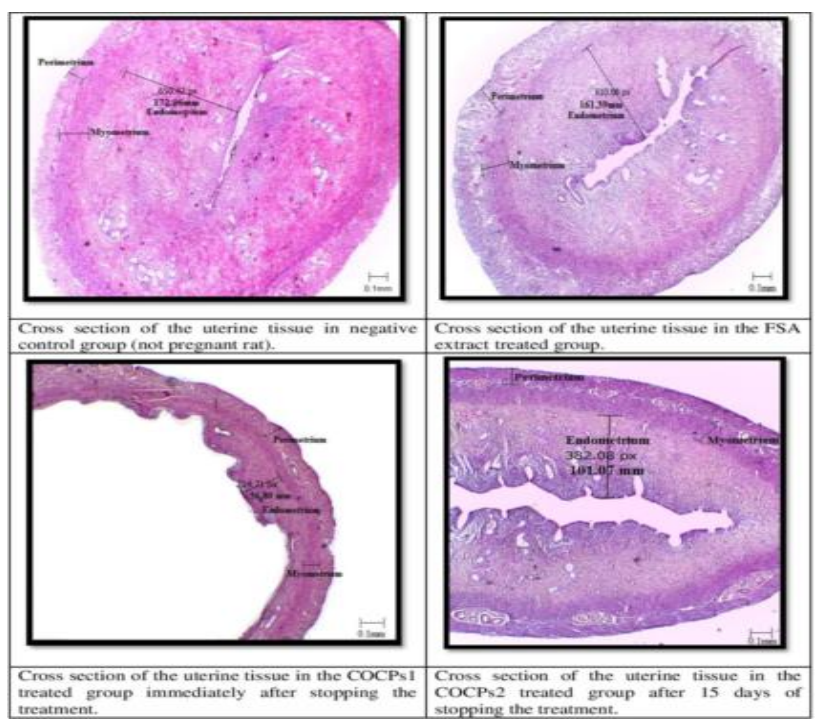

Figure 5: Cross section of the uterine tissue in negative control group (not pregnant rat), FSA extract treated group, COCPs1, treated group immediately after stopping the treatment and COCPs2 treated group after 15 days of stopping the treatment. 


\section{Comparison of endometrial gland density in the four groups}

As shown in Figure 6, the endometrial gland density in the normal negative group (not pregnant rats) were found to be $(38.16 \pm 2.03)$, in FSA extract treated group were found to be $(37.83 \pm 1.60)$, in COCPs1 treated group were found to be $(8.16 \pm 1.16)$ which revealed that the values were statistically significant with $p<0.001$, in COCPs2 treated group were found to be $(16.16 \pm 1.16)$ which revealed that the values were statistically significant with $p<0.001$. All values were expressed as the Mean \pm SD. The lowest number of the endometrial gland density was in COCPs1 treated group followed by COCPs2 treated group, then FSA extract treated group which was as same as the negative control group (not pregnant rats), the standard error shows these differences in Figure 8.

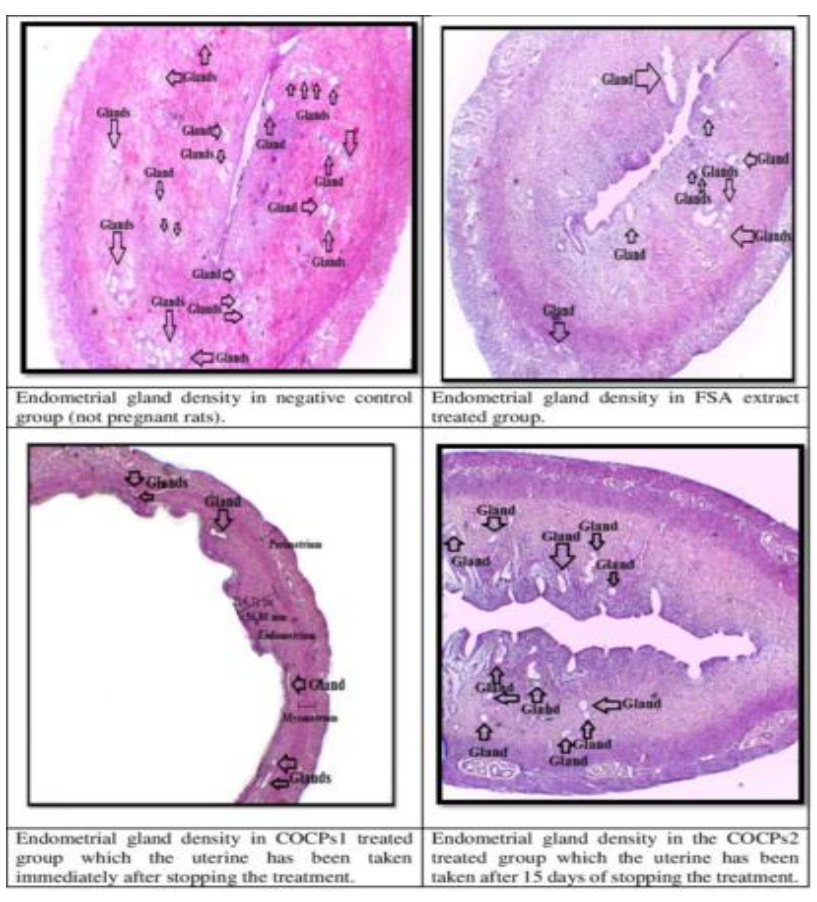

Figure 6: Endometrial gland density in the negative control group (not pregnant rats), FSA extract treated group, COCPs1 and COCPs2 treated group.

\section{Comparison of the histological endometrial tissues in the four groups}

As shown in Figure 7, the histological endometrial tissues in the negative control group was normal, the stromal cells were normal, the cytoplasm was clear, the number of glands was normal and there is no deterioration has been observed which was as same as the uterine tissues in the FSA extract treated group. In the opposite of COCPs treated group, the endometrial tissues have an abnormal deciduoid cell (decidual like cells) which is prominent cell borders and uniform with round to oval nuclei and their cytoplasm has small vacuoles.

\section{DISCUSSION}

\section{Comparison of FSH concentrations in the four groups}

The present study demonstrated the different concentrations of serum FSH in the four groups; negative control group (the normal not pregnant rats), positive control group (the normal pregnant rats), COCPs treated group and FSA extract treated group.

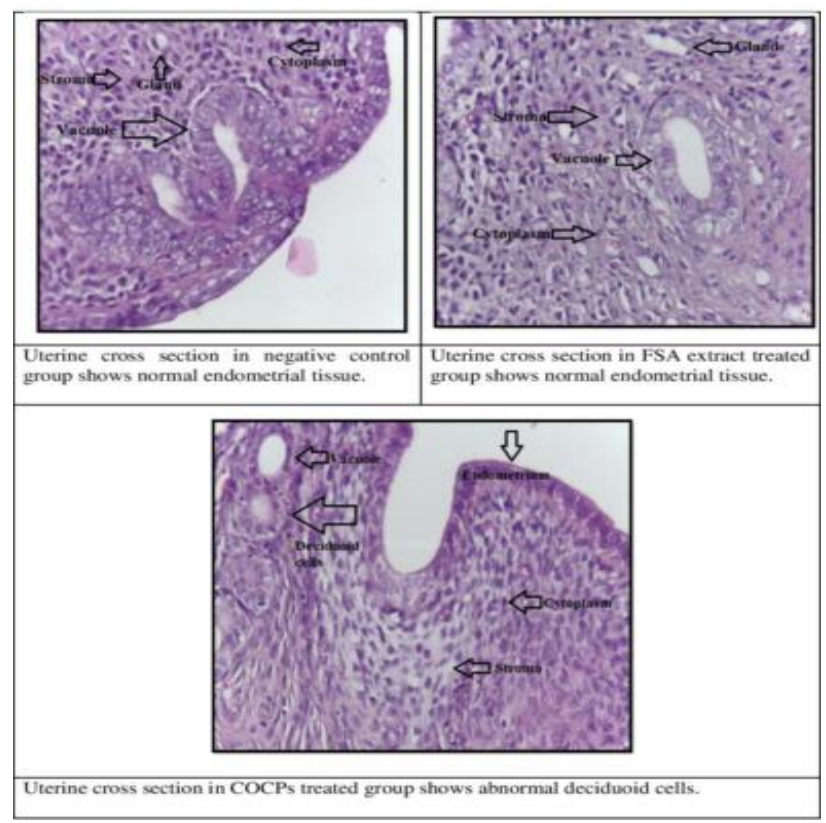

Figure 7: uterine cross section in negative control group, FSA extract treated group shows normal endometrial tissues and COCPs treated group shows abnormal deciduoid cells in the endometrial tissues.

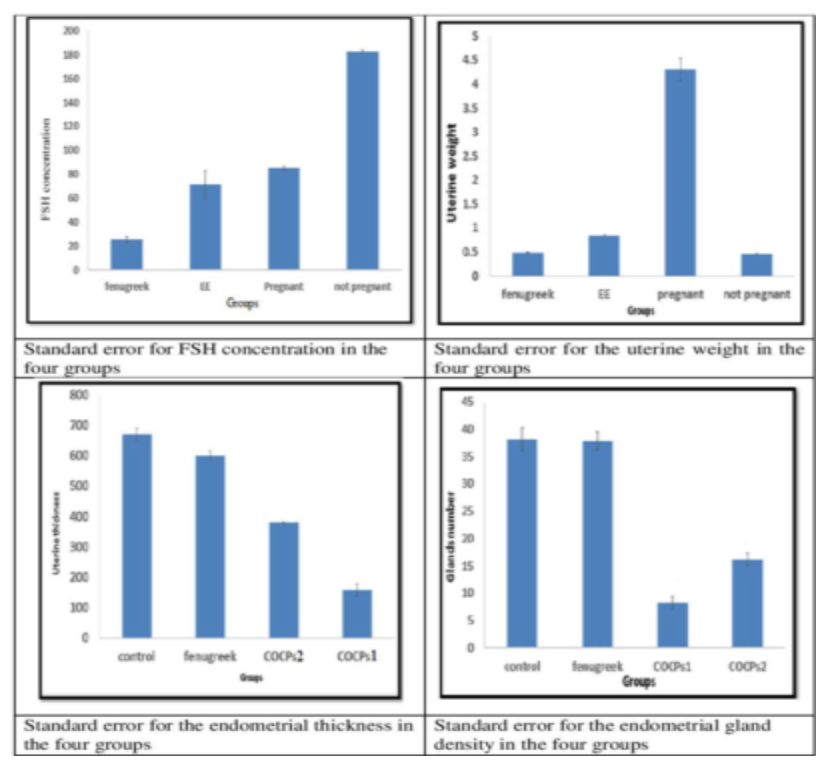

Figure 8: Standard error for FSH concentration, uterine weight, endometrial thickness and endometrial gland density in the four groups. 
In the first group; negative control group (the normal not pregnant rats), the FSH concentration was in the normal range $182.86 \mathrm{ng} / \mathrm{ml}$, which is high compared to the positive control group (the normal pregnant rats), in the not pregnant rats, the FSH secretions will be normal because the rats still ovulating due to FSH release which trigger the ovulation. ${ }^{13}$ But in the pregnant rats, the FSH was significantly low $84.86 \mathrm{ng} / \mathrm{ml}$ because the rats were pregnant, means there is no ovulation, the results were in the agreement that FSH level will decrease when the mammals are pregnant because of no ovulation. ${ }^{14}$

In the third group; COCPs treated group, the FSH concentration was significantly low $71.56 \mathrm{ng} / \mathrm{ml}$ and this observation was in the agreement that the FSH level will decrease when the females will be treated with contraceptive medications as the mechanism and pharmacodynamics of the contraceptive medications were related to decrease the level of FSH in the body, eventually stopping the ovulation and thereby no pregnancy will occur, this was proved and with agereement with many studies that amenorrhea which is absence of menstrual cycle associated with low FSH values and chronic anovulation. ${ }^{15,16}$

In the fourth group; FSA extract treated group, the FSH concentration was the lowest among all groups 25.62 $\mathrm{ng} / \mathrm{ml}$, it was lower than marketed COCPs almost three times and this prove the strong effectiveness of FSA extract compared to contraceptive medications and this shows the potential antifertility activity of FSA extract. ${ }^{17}$ The FSA extract has a strong effect in decreasing FSH level as observed which end by failed pregnancy because there is no ovulation since the level of FSH is too low. This effect is possibly due to the components present in the FSA extract specifically diosgenin; the bioactive constituent that is believed attribute to the antifertility effect of fenugreek. ${ }^{18}$

The value FSH was found to almost 3 times lower than the marketed contraceptive pills which indicates that the FSA extract was effective more than the marketed contraceptive pills at higher dose.

\section{Comparison of the uterine weight in the four groups}

In the negative control group (the normal not pregnant rats), the uterine weight were in normal range $0.46 \mathrm{~g}$ since the rats were not pregnant, while in the positive control group (the normal pregnant rats) the uterine weight was significantly high $4.30 \mathrm{~g}$ because the rats were pregnant so the uterine weight increased due to the weight of foetuses inside the uterine.

In the third group, COCPs treated group, the uterine weight was not significantly high $0.84 \mathrm{~g}$ as our observation.

In the fourth, FSA extract treated group, the uterine weight was as same as in the normal not pregnant rats
$0.46 \mathrm{~g}$ which shows that FSA extract has no effect on the uterine weight which resulted in altering the physiological condition of uterine.

\section{Comparison of the implantation rate in the four groups}

In the first negative control group (the normal not pregnant rats), the implantation rate was zero in this group because the rats didn't mate, so they didn't become pregnant, but in the positive control group (the normal pregnant rats) the implantation rate was high 10.66667 because the rats very fertilize so the implantation rate was high.

In the third group, COCPs treated group, the implantation rate was zero since the contraceptive medications prevent pregnancy. In the fourth group, FSA extract treated group, the implantation rate was zero which shows that fenugreek works as unfertilized agent to prevent pregnancy.

\section{Comparison of endometrial thickness in the four groups}

The endometrial thickness in the negative control and FSA extract treated group was normal with $177.37 \mathrm{~mm}$ and $159.02 \mathrm{~mm}$ respectively.

However, the endometrial thickness in COCPs1 treated group immediately after stopping the treatment was found to be $41.60 \mathrm{~mm}$, the thickness of endometrium become more thinner in contraceptive treated female rats and this observation was in the agreement that the uterine thickness will reduce when females will be treated with contraceptive medications as the mechanism and pharmacodynamics of the contraceptive medications were related to reduce the endometrial thickness, eventually changing the endometrium layer and thereby it will be difficult for implantation the fertilized egg. The endometrial thickness in COCPs2 treated group after 15 days of stopping the treatment was be to found 100.71 $\mathrm{mm}$ which still thin compared to the normal range and this is a sign that even after some time of stop taking the contraceptive pills, the side effects will be in the body. ${ }^{19,20}$

\section{Comparison of endometrial gland density in the four groups}

In the negative control and FSA extract treated group, the endometrial gland density was normal, the distribution and the number of the glands were normal in both groups, in the negative control group the gland number was to be found 38.16 and in FSA extract treated group the gland number were to be found 37.83 which is normal in both groups. ${ }^{21}$ While in COCPs1 treated group immediately after stopping the treatment was found to be 8.16 and in COCPs 2 treated group after 15 days of stopping the treatment was be to found 16.16. The glands number in both groups COCPs1 and COCPs2 treated group reduced which a remarkable sign of endometrial atrophy and it is 
also a sign that that even after stop taking the contraceptive pills the side effect will be in the body. ${ }^{20,22}$

\section{Comparison of histological uterine tissues in the four groups}

In the negative control and FSA extract treated group, the uterine tissues have a normal appearance, the endometrial cells; include both glandular and stromal cells exfoliating in ball or gland-like clusters, rarely as single cells. These glands reach from the endometrial surface through to the base of the stroma. ${ }^{23}$ Stromal endometrium is composed of large sheets of surface epithelial cells and distinct and dense cytoplasm. ${ }^{24}$ But in the COCPs treated group, the appearance of abnormal deciduiod cells (decidual like cells) has been observed due to COCPs administration. ${ }^{25}$

Owing to widespread use of hormonal contraceptives for therapeutic or contraceptive purposes a new endometrial morphology emerged. In combined contraceptive programs, the effect is exerted on the glands and stroma; the glands are small, straight, and inactive with no mitosis or secretion the stroma is very prominent and edematous is infiltrated by some neutrophils and shows striking pseudodecidual changes. The latter which may appear as fragments as frankly necrotic decidua distinguished due to COCPs administration. ${ }^{26}$

\section{CONCLUSIONS}

The current study demonstrated the potential antifertility activity of FSA extract. The study showed that $750 \mathrm{mg} / \mathrm{kg}$ effective more than the marketed combined contraceptive pills $0.05 \mathrm{mg} / \mathrm{kg}$ which shows that FSA extract can be as strong as standard contraceptive pills and this has been done by measuring the FSH level if to observe the ability of FSA extract to reduce the FSH level which is a sign of failed pregnancy and this mean that FSA extract can be used as antifertility agent and it will be effected like the marketed contraceptive pills.

Administration of FSA extract resulted to alterations in the serum reproductive hormone concentration; FSH concentration decreased almost three times with no significant toxicity and fatal death recorded.

FSA extract has no effect on the uterine weight while COCPs caused insignificant increase in the uterine weight. The endometrial thickness in FSA extract was normal while it significantly reduced in COCPs treated group. The endometrial gland density was normal in FSA extract treated group while it significantly reduced in COCPs treated group which is a sign of endometrial atrophy. The histological uterine tissue were normal in FSA extract treated group while it showed abnormal appearance of deciduiod cells (decidual like cells) in COCPs treated group.
Funding: No funding sources

Conflict of interest: None declared

Ethical approval: The study was approved by the Institutional Ethics Committee

\section{REFERENCES}

1. Harper MJK. In search of a second contraceptive revolution, Sexuality, Reproduction \& Menopause, 2005, 3(2):59-67.

2. Cohen SA. As global commitment to reproductive health intensifies, U.S. leadership \{more important than ever, Guttmacher Policy Review. 2011;14(1):26.

3. Sharma S, Dayaratna V. Creating conditions for greater private sector participation in achieving contraceptive security, Health Policy. 2005;71(3):347-57.

4. Ross J, Weissman E, Stover J. Contraceptive Projections and the Donor Gap: Meeting the Challenge, Brussels, Belgium: Reproductive Health Supplies Coalition. 2009.

5. Nass SL, Strauss JF. New Frontiers in Contraceptive Research: A Blueprint for Action, Washington, DC: National Academies Press. 2004.

6. Greep RO, Koblinsky MA, Jaffe FS. Reproduction and human welfare: a challenge to research, BioScience. 1976;26(11):677-84

7. Shufelt CL, Merz CNB. Contraceptive hormone use and cardiovascular disease. Journal of the American College of Cardiology. 2009;53(3):221-31.

8. Sabatini, R, Cagiano R, Rabe T. Adverse effects of hormonal contraception. Journal für Reproduktionsmedizin und Endokrinologie-Journal of Reproductive Medicine and Endocrinology. 2011;8(1):130-56.

9. Kassem, A, Al-Aghbari A, Molham AH, Al-Mamary M. Evaluation of the potential antifertility effect of fenugreek seeds in male and female rabbits. Contraception. 2006;73(3):301-6.

10. Dixit P, Ghaskadbi S, Mohan H, Devasagayam T. Antioxidant properties of germinated fenugreek seeds. Phytotherapy Research. 2005;19(11):977-83.

11. Patrick TS Ma, Yamamoto T, Goldstein JL, Brown MS. Increased mRNA for low density lipoprotein receptor in livers of rabbits treated with 17a-ethinyl estradiol. 1985.

12. Seiler T, Kaemmerer M, Mierdel P, Krinke HE. Ocular optical aberrations after photorefractive keratectomy for myopia and myopic astigmatism. Archives of ophthalmology. 2000;118(1):17-21.

13. Itskovitz-Eldor J, Kol S, Mannaerts B. Use of a single bolus of GnRH agonist triptorelin to trigger ovulation after $\mathrm{GnRH}$ antagonist ganirelix treatment in women undergoing ovarian stimulation for assisted reproduction, with special reference to the prevention of ovarian hyperstimulation syndrome: preliminary report: short communication. Human Reproduction. 2000;15(9):1965-8. 
14. Hirano M, Igarashi A, Suzuki M. Dynamic changes of serum LH and FSH during pregnancy and puerperium. The Tohoku journal of experimental medicine. 1976;118(3):275-82.

15. Leon S, Darney PD. Oral contraception. A clinical guide for contraception (5th ed.). Philadelphia: Lippincott Williams \& Wilkins. ISBN 978-1-60831610-6. 2011:19-152.

16. Devleta B, Adem B, Senada S. Hypergonadotropic amenorrhea and bone density: new approach to an old problem. Journal of bone and mineral metabolism. 2004;22(4):360-4.

17. Kassem A, Al-Aghbari A, Molham AH, Al-Mamary M. Evaluation of the potential antifertility effect of fenugreek seeds in male and female rabbits. Contraception. 2006;73(3):301-6.

18. Francis G, Kerem Z, Makkar HPS, Becker K. The biological action of saponins in animal systems: a review. Br. J. Nutr. 2002;88:587-605.

19. Benagiano G, Pera A, Primiero FM. The endometrium and hormonal contraceptives. Human Reproduction. 2000;15(1):101-18.

20. ESHRE Capri Workshop Group. Ovarian and endometrial function during hormonal contraception. Human Reproduction. 2001;16(7):1527-35.

21. Wang CK, Robinson RS, Flint APF, Mann GE. Quantitative analysis of changes in endometrial gland morphology during the bovine oestrous cycle and their association with progesterone levels. Reproduction. 2007;134(2):365-71.

22. Azzopardi JG, Zayid I. Synthetic progestogenoestrogen therapy and uterine changes. J Clin Pathol 1967;20:731-8.

23. Moriarty AT, Cibas ES. Endometrial cells: the how and when of reporting. In: Solomon D, Nayar R eds. The Bethesda System for Reporting Cervical Cytology, 2nd Ed. New York: Springer-Verlag, Inc. 2004:57Y65.

24. DeMay RM. The Pap smear. In: The Art and Science of Cytopathology. Chicago: ASCP Press, 1996:120Y9.

25. Deligdisch L. Effects of hormone therapy on the endometrium. Modern pathology: an official journal of the United States and Canadian Academy of Pathology, Inc. 1993;6(1):94-106.

26. Ober WB. Effects of oral and intrauterine administration of contraceptives on the uterus. Human pathology. 1977;8(5):513-27.

Cite this article as: Hilles AR, Allow AK,

Mahmood S. Evaluation and comparison of the antifertility potential activity and adverse effects of Trigonella foenum-graecum seeds and combined oral contraceptive pills in female rats. Int J Reprod Contracept Obstet Gynecol 2016;5:680-8. 